International Journal of Business and Management Review

Vol.8, No.1, pp.18-38, January 2020

Published by ECRTD-UK

Print ISSN: 2052-6393(Print), Online ISSN: 2052-6407(Online)

\title{
EFFECT OF PUBLIC DEBT ON ECONOMIC GROWTH OF NIGERIA: AN
} EMPIRICAL INVESTIGATION

\author{
AJAYI, Ibidolapo Ezekiel \\ Department of Finance, Faculty of Management Sciences, Ekiti State University, Ado-Ekiti \\ ajayidolapo@gmail.com
}

\section{EDEWUSI, Damilola Gabriel}

Department of Finance, Faculty of Management Sciences, Ekiti State University, Ado-Ekiti omoedewusi@yahoo.com

\begin{abstract}
This study examined the effect of public debt on economic growth of Nigeria. Specifically, the study determined the impact of domestic debt on the economic growth of Nigeria; assessed the effect of external debt on the economic growth of Nigeria and analyzed the relationship public debt and the economic growth of Nigeria. Secondary time series data spanning thirty-seven years (1982-2018) was gathered in the study. Data gathered in the study was estimated using descriptive statistics, unit root test, Johansen co-integration test and vector error correction model. Discoveries from the study suggests that external debt exerts a negative long run and short run effect on economic growth of Nigeria and domestic debt was ascertained to exert positive long run and short run effect on economic growth of Nigeria. Based on these findings, the study suggested that policy makers should integrate appropriate measures towards ensuring suitable management of domestic debts; government should ensure that contracted national debts are directed towards encouraging investment in the country and government through necessary monitoring committees should ensure that national debts are directed toward the provision of basic amenities and services required for the development of communities and societies of the nation.
\end{abstract}

KEY WORDS: Public Debt, Domestic Debt, External Debt

\section{INTRODUCTION}

All over the world, the issue of public debt proliferation suffered by numerous developing countries has attracted global attention; this experience which is occasioned by the fall in oil prices, exchange rate volatility, increasing interest rate etc. has exerted a negative effect on the economy of developing economies across the globe especially Nigeria (Favour, Ideniyi, Oge and Charity, 2017). Debt or borrowings have been described as an important instrument of fiscal policy available to government to fund the development of a nation. Debt is employed in causing the settlement of expenditures that will ultimately increase productivity and improve the growth of the economy (Muhammad, Ruhaini, Nathan and Arshad, 2017). Although, studies have ascertained a negative impact of public debt usually a particular level on the growth of most developing economies (Panizza and Presbitero, 2012); Reinhart and Rogoff, 2010). It has been that budget deficits demonstrate that government expenditure is high relative to its revenue, this gap has been 
identified to be filled with public debt (Mankiw, 2013). Public debt which includes both internal (domestic) and external debts is considered when the revenue realized by the governable is insufficient for its projected expenditures (Rahman, 2012).

Public debt which is also referred to as national debt owed by the government or the aggregate of borrowings of all government units such the federal, state and local government (Idenyi, Igberi and Anoke, 2016). Public debt is described as the aggregate of borrowings acquired by government bodies of a country; this includes funds owned to private organizations, public entities, foreign government etc. In the discourse of public debt, future pension payments, government liabilities and good and services received by government on credit are all considered. Idenyi, Igberi and Anoke (2016) affirmed that public debt forms one of the numerous approaches of financing government expenditures; although governments can instruct the Central Bank to produce and release funds to it so as to avoid the interest payment attached to government debts, this method will unarguably control interest cost but will not get rid of the debt. In fact, the authors further maintained that the ultimate result of such action is hyperinflation. Also, government can also increase tax in its bid to service its debt (Idenyi, Igberi and Anoke, 2016).

The spate of public debt especially in developing countries since the beginning of the $21^{\text {st }}$ century has been alarming. This is undoubtedly because the heightening level of government debt in any country can be deleterious to the growth its economy especially if not properly managed (Favor et al., 2017). However, public debt intensifies when the government consistently experience budget deficits. Put differently, the aggregate of borrowings owed by government at all level is referred to as public debt; such borrowings can be caused when services like pension payment owed to its employees or in form of contract entered by the government with a backlog of owing (Favor et al., 2017). Also, government can initiate borrowings through treasury bills, bonds, issuing securities and directly from international financial institutions. Usually, borrowed funds are used in enhancing the productivity level and developing human capital through the provision of employment opportunities, deliver adequate infrastructural facilities and expanding the scope of private investment thereby increasing economic growth and development. Albeit, as the height of public debt of countries maintained an increased level during the 1980s, a noticeable number of countries with a large stock of government debt received some financial support from the international financial groups. The cause for this assistance is to enhance productivity within less developed countries, reducing external debt stock, ennobling the standard of level of living of people and ultimately increasing the economic growth of Nigeria (Idris and Ahmad, 2017).

Economic growth has been referred to as the aggregate of the final output that a country can create within a year judged by the market price of the products taking cognizance of price variation and the imputed cost of the economy's produced goods and services less net income from abroad (Favor et al., 2017). An increase in the gross domestic product of a country is noticed as the productive capacity of the country accrues, especially when measured relative to other periods. Hence, economic growth is observed when the total goods and services of a country increases relative to the previous years. The association between external debt and the economic growth of 
developing countries has over the years been recognized amongst policy holders and researchers all over the world (Idris and Ahmad, 2017). Meanwhile, the implication of domestic debt has been insignificantly considered especially in the literature due to the uncritical nature of its conditions. This connotes that prior to the advent of the Structural Adjustment Programme (SAP) in the 1980s, several African countries accorded an insignificant interest to the adverse effect caused by domestic debts to the economies of most of these countries especially Nigeria. This has caused numerous countries to resort to their central banks in their bid to amass resources necessary for debt servicing (Idris and Ahmad, 2017). Essien et al., (2016) asserted that this event has triggered numerous macroeconomic issues including liquidity challenge, increasing inflation rate, high monetary expansion, limited loanable funds for private investment among others.

However, Cecchetti, Moharty, and Zampoli (2010) contended that the lack of changes in fiscal policy, debt will continue to accrue as government expenditure has always been on the increase despite declining revenue. They further mentioned that as the risk embedded in the issuance of bonds continue to increase and the increasing population may continuously occasion the dynamism in public debt. Hence, the current debt crisis has revivified the policy and academic discussion concerning the effects of public debt on economic growth. Although the upswing in academic researchers conducted on this focus are bereft of adequate empirical evidence from countries of the world on the connection between public debt and economic activity.

\section{Statement of the Problem}

The inability of Nigeria to accumulate domestic resources so $\mathrm{s}$ to fill the usual budget deficit experienced in the country over the years occasioned the consistent dependence on public debt especially foreign debt which is often typified by adverse lending conditions, instability of foreign exchange rates and the potential repudiation that occasions debt overhand, hence exerting negative effects on the economic growth of Nigeria (Akinwunmi and Adekoya, 2018). This issue has also been ascertained to impede domestic capital creation thereby triggering the reduced provision of basic amenities for citizens in the country (Udoka et al., 2010). The erstwhile Minister of Finance corroborated this position as she affirmed that the main cause of the unimpressive development state of Nigeria is the inadequacy and bad condition of infrastructures in the country.

The consistent upsurge in Nigerian's domestic and external debt profile without an obvious growth in its capacity usage have over time caused the frequent quest for debt scheduling and cancellation expired by Nigeria and several other developing countries across the globe (World Bank, 2002). Following the issues created by endogenous factors stemming from domestic debt which includes extra-tax burden, deflection of the society's limited capital form the productive private sector to the unproductive public sector and the economic exogenous factors such as exchange rate and interest rate particularly couple with the oil price drop which led Nigeria into its first recession in 2004 and also intensified its debt stock cause the need for debt relief which was initiated in 2005 (Nwankwo, 2010). However, despite the cancellation of Nigeria's membership in Paris and London Club in 2006, the country still employed deficit financing especially in 2009 and 2010 when it provided debt instruments of about N524billion and N867billion respectively, this attempt 
was clearly awkward as it occasioned the payment of an increased interest rate of \$42billion owed to the Paris Club (Nwankwo, 2010).

Numerous studies aimed at examining the effects of public debt on economic growth have been carried out over time across countries of the world. Noticeably, a significant number of these studies and other related researches are bereft of strategic empirical evidences in developed countries, Nigeria and other developing countries (Saifuddin, 2016; Idenyi, Ogonna and Ifeyinwa, 2016; Jernej, Aleksander and Miroslav, 2014; Muhammad, Ruhaini, Nathan and Arshad, 2017; Siew-Peng and Yan-Ling, 2015; Egbetunde, 2012; Amilcar, 2016; Rahman, 2012; Hadhek and Fatma. 2014; Naeem, 2017; Muhammad, 2017; Mousa, and Shawawreh, 2017; Ndieupa, 2018; Matandare and Tito, 2018; Brini, Jemmali and Ferroukh. 2016; Alfred, 2014; Panizza and Presbitero, 2013; Blake, 2015 and Victor and Joseph, 2016). Following the gap in the research focus and literature of previous researches, this study empirically examines the effect of public debt on economic growth of Nigeria.

\section{Research Objectives}

The broad objective of this study is to examine the effect of public debt on economic growth of Nigeria. The specific objectives of the study are:

i. To determine the impact of domestic debt on the economic growth of Nigeria.

ii. To assess the effect of external debt on the economic growth of Nigeria

iii. To analyze the relationship public debt and the economic growth of Nigeria.

\section{Research Hypotheses}

$\mathrm{HO}_{1}$ domestic debt has no significant impact on the economic growth of Nigeria.

$\mathrm{H}_{2}$ external debt does not significantly affect the economic growth of Nigeria.

$\mathrm{HO}_{3}$ there is no significant relationship between public debt and economic growth of Nigeria.

\section{LITERATURE REVIEW}

\section{Conceptual Clarification}

\section{Public Debt}

Public debt also referred to as government debt or external debt is conceptualized as the aggregate debts owed by a certain country to individuals, corporations and countries within the country or abroad. Government debts typify all forms of government borrowings at all levels of government (Christabel, 2013).Public debt forms part of the finance approach adopted by governments all over the world, although this approach is often resorted to when all measures have been exhausted, in fact the measure is considered favorable relative to other measures which includes the creation of money and the sale of national assets (Martin, 2009).

Notwithstanding, it has been observed that an increased level of external debt impacts negatively on the trade ability and economic prosperity of most nations (Asley, 2002). Also, debt overhang influences economic improvement and the effectiveness of monetary policies, export growth and 
reduces the severity of trade policies thereby enhancing the friendliness of the market and by implication increasing trade openness. Despite this, debt if not adequately utilized reduces the level of economics development (Muhtar, 2004). He further maintained that debt services ceases the resources required for socioeconomic development. Ojo (2009) averred that the increased debt incurred by Nigeriais undoubtedly one of the issues that occasioned the SAP implemented in 1986 to create a sustainable economic growth.

Debts have been categorized into two broad forms such as the external debt which is contracted outside the country and domestic debt which is described as debts raised from individual and corporations within the country. Furthermore, the reproductive debt and dead weight debt are other classification of debts. The former is referred to as a loan raised to cause the acquisition of assets that is urgently required for productive activities e.g. borrowing for electricity, refineries, acquisition of factors etc. Meanwhile, the latter - deadweight debt is referred to as debts contracted to execute unproductive activities e.g. debt undertaken to promote war or finance current expenses (Eaton, 1993).

Nda (2007) asserted that public debt is an effective measure to enhance economic growth especially when it is adequately used in developing national assets which could provide job opportunities. Although public debt if mismanaged or unproductively utilized, this triggers numerous economic adversities; this premise the idea that debt should be resorted to when its urgent and when measures for its adequate utility and management is in place (Nda, 2007).

\section{Economic Growth}

Economic growth has over time been regarded as an all-important goal of economic policy with a robust study occasioned to clarify how this aforesaid goal can attained (Fadare, 2010). Economic growth has attracted the concern of scholars. Khorravi and Karimi (2010) affirmed that classical studies determined that economic growth is grossly dependent on labour and capital as factors of production. Economic growth describes the increase of the country's national output or gross domestic product. It also represents an increase in the economic capacity to produce goods and services relative to their output in the previous years (Abbas, 2005). A growth is caused in the economic whenever a unit of production is successfully inputted into the economic system. Hence we say that economic growth describes the amount of goods and services created, with less concern about how the products or services are produced (Matiti, 2013). Economic growth can be estimated in nominal terms e.g. inflation or adjusted inflation by the percentage rate of increased in national output (GDP). Notwithstanding, economic growth estimates growth in monetary terms and considers no other areas of development (Ayres and Warr, 2006).

\section{Nexus between Public Debt and Economic Growth}

An effectively managed public debt enhances the stability and growth of the economy through judicious utilization of the revenue and repaying the borrowings in due time with limited interest and curtailing unnecessary financial risk (Matiti, 2013). In fact, the effect of domestic debt as part of the complex issues influencing the structural stability of the Nigerian economy over time.Even 
after the debt cancellation in 2003, the issues of fiscal balance in Nigeria have continued to attract the interest of scholars especially after the implementation of the recent economic policy in 2017 titled "Nigerian Economic Recovery and growth Plan" directed towards reviving the impressive position of economic productivity (Idris and Ahmad, 2017). Debt challenges is occasioned by debt servicing which consumes a noticeable part of savings created for public investment as well as the increasing uncertainty connected with the future increase in government financial crisis. Based on thispremise, it is critically required for debt servicing to not reduce funds provided for the improvement of human development (De coyuntura, 1999).

Albeit, this is a far cry from the situation in Nigeria, following the unfavorable situation of infrastructures, low level of employment, increasing poverty ratio and high illiteracy level. More importantly, a country with a high debt profile like Nigeria that leverages on oil revenue couple with the increase debt servicing cost is likely to face an increased exploration and reduction of this product beyond a sustainable level, thereby enhancing the negative effect of unproductive debt in the long run (Idris and Ahmad, 2017). Additionally, the state of debt crisis in Nigeria have negatively affected several economic activities, this is mainly caused by the fall in the prices of international commodity. Because the main object of public borrowing is to improve economic growth and maintain a sustainable economic development, the Nigerian public sector has over time negotiated for an increased domestic borrowing relative for external borrowing so as accelerate productive investment. Despite this, the heightening growth of domestic debt reflects the pattern of debt utility by Nigerian government. However, the growthin the debt has not been satisfactorily used for desirable investments that will create future revenue instead of consistently triggering other debt contract to finance the ineffective and unproductive programmes lacking growth prospect and exposing the public sector to more critical financial risk and fiscal imbalance (Idris and Ahmad, 2017).

\section{THEORETICAL REVIEW}

\section{The Ricardo Theory of Public Debt}

The theory was postulated by Ricardo in 1819. The author maintained that the expected and unexpected expenditures of government basically include payments approved to maintain economic balance despite the ineffectiveness of most laborers in the economy. In a letter sent to McCulloch by Ricardo in 1986, he asserted that public expenditure was an unproductive economic activityimplemented by the state. Following this identified fiscal gap, Ricardo's theory was focused on the increasing burden stemming from the society, which is a product of unproductive public expenditures (Precious, 2015).

The Riacrdo's theory of public debt suggests that financing public expenditure could be productively attained by sourcing funds from sectors and communities with excess economic resources so as to reduce inequality.He stated that the reason for this is because the prioritization of a certain sector for the settlement of public expenditure does not impact positively on the growth of the economy but rather it impoverishes the state despite large amount of public debts and taxes 
raised (Ricardo, 1819). In a similar way, the author argued that the payment of interest of debt extorts significant amount of wealth from the society to a different economy thereby impoverishing the state. This according to Okoye, Modebe and Evbuomwan (2013) necessitates the need for countries to contract productive debts as improves economic growth.

\section{Empirical Evidences}

\section{Evidence from Nigeria}

Akhanolu, Babajide, Akinjare, Oladeji and Osuma, (2018) evaluated the effect of public debt on economic growth in Nigeria. The quantitative research technique was adopted, secondary data from 1982-2017 was gathered. Inferential analyses were conducted and findings from the study demonstrated that internal debt exerts a positive impact on economic growth while and external debt revealed an inverse relationship with economic growth. Premise on the findings, the study suggested that borrowed funds particularly external debt should be minimized.

Favour, Ideniyi, Oge and Charity (2017) assessed public debt and economic growth in Nigeria. Specifically, the study investigate extent to which foreign debt impact national output in Nigeria; ascertained if domestic debt significantly impact national output in Nigeria; determined the degree of causal relationship existing between the explanatory variables and national output in Nigeria. The study adopted the quantitative research method. Secondary time series data spanning fortyfive years (1970-2015) was amassed in the study from the Central Bank of Nigeria. Result stemming from the study revealed that external debt have significant negative impact on economic growth within the period under study; domestic debt (DMD) has significant negative relationship with economic growth within the period under consideration and external debt and domestic debt granger cause RGDP in Nigeria with causality running from external debt and domestic debt to RGDP. Premise on the result, the study suggested government should reduce external debt and the ones obtained should be strictly used for purposes intended to ensure positive effect and government should cut down on domestic borrowing and ensure that the already borrowed.

Egbetunde (2012) examined public debt and economic growth in Nigeria. The study employed the quantitative research method. Secondary time series data spanning forty years (1970-2010). Data gathered in the study was analyzed using Augmented Dickey Fuller and Philip Perron test. Results stemming from the study revealed that public debt exerts a long run impact on economic growth. The findings of the VAR model also demonstrated that there is a bi-directional causality between public debt and economic growth in Nigeria. based on this findings, the study recommended that Nigeria government should source for loans within the economy.

Bakare, Ogunlana, Adeyeye and Mudasiru (2016) empirically analyzed the effects of domestic debt on Nigerian economic growth. The study adopted the quantitative research method. Secondary time series data spanning thirty-two years (1980-2012) were collated from the Central Bank of Nigeria Statistical Bulletins and Annual Reports, the Debt Management Office [DMO], the National Bureau of Statistics [NBS], and other cognate publications. Data gathered in the study 
was analyzed using Ordinary Least Square Regression (OLS) technique. Findings gathered from the study revealed that a positive relationship between domestic debt and economic growth. The study recommended that mechanisms should be put in place to monitor the impact of new borrowing on overall debt sustainability based on the evolution of the debt indicators and provide prompt fiscal rectification.

Rafindadi and Musa (2018) empirically analyzed the impact of public debt management strategies on Nigeria's debt profile. The study specifically assessed the impact of debt refinancing (DRF), and measured the impacts of debt forgiveness (DF) and debt conversion (DCV) scheme on the public debt profile of Nigeria. The study employed the econometric research approach as secondary time series data spanning thirty-seven years (1981-2016) were gathered from the Central Bank of Nigeria annual statistical bulletin, Debt Management Office Records and World Development Index (WDI). Data gathered in the study were analyzed inferentially. Findings stemming from the study showed that debt refinancing has negative impact on total debt profile in Nigeria. Furthermore, the study ascertained that debt forgiveness was detected to have significant negative impact on the debt profile of the country while debt conversion on its part was found to be having significant effect on the Nigeria's debt profile. Following these findings, the study suggested that government should strengthen debt refinancing in order to reduce debt profile of the country, seek for debt forgiveness and provide more instruments for debt conversion with a view to drastically reduce the Nigeria's national debt profile.

Oyedele, David and Omojola (2016) assessed the effect of public on economic growth in Nigeria. The quantitative research method was adopted. Secondary data spanning forty-one years (19702011) was collated from the CBN Statistical Bulletin, 2011 Edition, and World Development Indicators (WDI). Data gathered in the study was analyzed using econometric techniques. Result from the study demonstrated that that there exist no long-run relationship between public debt and economic growth in Nigeria; the study also affirmed that there exist a positive but non-significant relationship between per capital domestic public debt and economic growth while a negative and not significant relationship was found to exist between per capita external public debt and economic growth. Following these findings, the study suggested that government needs to be more transparent and committed to the course of the masses by putting borrowed money into highly productive sectors.

Idris and Ahmad (2017) examined that the productivity of public debt borrowing and economic growth in Sub-Saharan region. The study employed the autoregressive distributed lag model. Secondary time series data spanning thirty-five years was collated in the study. Econometrics estimation techniques were adopted and resulting from the analyses is the following discovery: domestic debt exerts a negative effect on economic growth. Based on these findings, the study suggested that fiscal policy practitioners and other related policy makers should earmark substantial attention to the productive utilisation of any internally borrowed funds and ensure that resources are allocated to specific growth-oriented programmes and that adequate capacities for loan-repayment are well-established. 
Dada (2012) assessed the effect of public debt on economic growth in Nigeria. The quantitative research approach was adopted as secondary time series spanning thirty-nine years (1970-2009) was gathered in the study. Inferential estimation techniques unit root test, cointegration test and ordinary least square method of estimation were used in analyzing data collated in the study. The study's result revealed that hat there exist no long-run relationship between public debt and economic growth in Nigeria; the study also affirmed that there exist a negative and non-significant relationship between per capita public debt and economic growth. Premise on the findings, the study suggested that government needs to be more transparent and committed to the course of the masses by putting borrowed money into highly productive sectors that will improve the productive capacity of the economy.

Ideniyi, Ogonna and Ifeyinwa (2016) examined public debt and public expenditure in Nigeria. The qualitative research method was used as secondary time series data spanning thirty-five years (1980-2015) was gathered in the study. The econometrics estimation techniques such as co integration, vector error correction model and Wald test were employed in analyzing the study's data. Findings from the study revealed that there is no long run relationship between public debt and public expenditure in Nigeria, the study also discovered that government capital and recurrent expenditure has significant positive relationship with public debt in the Nigerian economy. Based on these findings, the study advocated for the introduction of planning-programming budgeting systems (PPBS) and Zero based budgeting (ZBB) in preference to the current practice of incremental budgeting (IB) in our public finance at both federal and state level.

\section{Evidence from Other Developing Countries}

Saifuddin (2016) analyzed public debt and economic growth in Bangladesh. The study adopted the quantitative research approach as secondaary data for the period of 1974-2014 were collated in the study. Data gathered in the study were analyzed using the Augmented Dickey-Fuller test and the TSLS repression analysis. Findings stemming from the study revealed that that public debt is positively related to both investment and economic growth. This result reveals that financial resources pooled through government debt in Bangladesh is used for productive investment.

Serrao (2016) assessed the impact of public debt on economic growth in advanced countries.the study employed the econometric research design as secondary time series data spanning sixty four years (1964-2009) was collated for twenty advanced countries including Australia, Austria, Belgium, Canada, Denmark, Finland, France, Germany, Greece, Ireland, Italy, Japan, Netherlands, New Zealand, Norway, Portugal, Spain, Sweden, the United Kingdom, and the United States. Inferential analysis was adopted and findings that resulted from the study revealed that there exists a negative connection between public debt and economic growth in advanced countries. Following this findings, the study advocated for new strategies for public debt management in advanced economies, taking into account their economic and financial performance.

Muhammad (2017) examined the relationship between public debt and economic growth in the South-East Asia countries. The quantitative research method was adopted as secondary data 
spanning ten years (2006-2015) were obtained from the World Bank National Accounts data, and OECD National Accounts Data. Data gathered in the study were analyzed using the VAR analytical technique, granger causality and other inferential analyses. Findings derived in the study showed that public debt affects economic growth of a country significantly especially in the long run.

Mousa and Shawawreh (2017) analyzed the impact of debt on the economic growth of Jordan. Specifically, the study investigate the impact of external debt on gross domestic product; assessed the impact of domestic debt on gross domestic product; assessed the impact of debt service on gross domestic product and evaluated the impact of public debt on gross domestic product. The quantitative research approach was used as the study consider secondary time serie data spanning fifteen years (2000-2015). The least squares method and regression model were adopted in analyzing the study's data. Findings gathered from the study revealed that there is a negative impact of total public debt, especially the external debt on economic growth. Following this findings, the study suggested that nations should rather depend on the available internal resources than depending on external debt.

Ndieupa (2018) assed the effect of public debt on economic growth of Central African Economic and Monetary Community (CEMAC). The panel research design was adopted as panel data spanning sixteen (2000-2015) was amassed from developing countries namely Gabon, Cameroon, the Central African Republic, Chad, the Republic of the Congo and Equatorial Guinea. The study's data was examined using inferential analyses. Discoveries from the study revealed that public debt has an adverse and statistically significant effect on economic growth.

Matandare and Tito (2018) evaluated public debt and economic growth un Zimbabwe. The study employed quantitative research design. Secondary time series data spanning thirty six years (19862016) were gathered from the World Development Indicators database. Data gathered in the study were analyzed inferentially. Findings revealed in the study showed that there exists a negative significant relationship between external debt and economic growth in Zimbabwe. The study also ascertained that exchange rate and inflation were also found to have negative significant relationships with economic growth in Zimbabwe and external exerts a significant positive relationship with economic growth. Based on the findings, the authors advanced that the government should step up efforts to boost sources of domestic revenue to finance its growth plans as external debt accumulation weighs down economic growth and suggested the need to diversify the economy is crucial as government should develop new sectors which can generate revenue to contribute towards economic growth.

Brini, Jemali and Ferroukh (2016) reexamined public debt and economic growth in Tunisia. The quantitative research design was adopted as secondary data spanning 23 years (1990-2013) was gathered. Data collated in the study was analyzed using inferential analyses such as Autoregressive distributed lag model ARDL. Findings demonstrated in the study revealed that public debt and total debt service exerts a negative and significant effect on economic growth in the long run and 
in the short and long run there is a unidirectional Granger causality between public debt and economic growth. Again, the study affirmed that there is a bi-directional Granger causality between total debt service and economic growth in the long run. While, there is no evidence of short run causality. Following the findings, the study suggested that the government must identify the solution for reducing the public debt, which will ultimately increase the economic growth.

Siew-Peng and Yan-Ling (2015) assessed public debt and economic growth in Malaysia. The study particularly examined whether other indicators of debt burden, such as budget deficit, budget expenditure, and external debt service and government consumption, have an impact on economic growth. The study employed the quantitative research method. Secondary time series data over the period 1991 to 2013 was collated. Inferential analyses were conducted on the data gathered in the study. Results stemming from the analyses revealed a negative association between diet and growth. The study also discovered that budget deficit, government consumption and external debt service are a decreasing function of GDP.

Khan, Rauf, Mirajul-haq, Anwar (2016) examined the impact of public debt on economic growth of Pakistan. The study adopted quantitative research method as secondary data over the period of 1972 to 2013. Data gathered in the study was examined using inferential analyses. Results revealed in the study showed that that public debt and economic growth has positive but statistically insignificant relationship. The study also revealed that high rate of population growth affects economic growth adversely.

Said and Yusuf (2018) examined public debt and economic growth in Tanzania. The quantitative research approach was adopted as secondary time series data spanning forty-five years was collated. Co-integration and Vector Error Correction Mechanism (VECM) Approach were used in analyzing data collated in the study. The VECM estimate showed that there is a negative relationship between public debt and economic growth in Tanzania over the study period. In addition, granger causality test revealed that there is no causal relationship between public debt and economic growth. Premise on these findings, the study suggested Government and policy makers should stop the accumulation of external debt stock overtime and prevent concealing of the motive behind external debt; external debts should be used only for productive investment of highest priorities that would help in yielding returns for economic reasons (productive purposes) and not for social or political reasons.

Mwaniki (2016) evaluated the effect of public debt on the gross domestic product in Kenya. The study specifically analyzed the effect of external debt on GDP; assessed the impact of advances from commercial banks on GDP; estimated the effect of overdraft from central bank of Kenya on GDP and evaluated the effect of government securities on GDP. The study employed the OLS regression and causal research design and secondary data spanning twelve years (2003-2015) was gathered. Data amassed in the study were analyzed inferentially. Findings resulting from the analyses revealed that bank loans, external debt and government securities have a significant relationship with gross domestic product of Kenya. Following these findings, the study 
recommended that the government should encourage sustainable domestic and external borrowing and utilize funds in productive economic areas.

\section{RESEARCH METHODS}

This study focused on the impact of public debt on economic growth in Nigeria. However, this study focused particularly on the impact of domestic debt, external debt on the economic growth of Nigeria. The study will cover a period of thirty-seven (37) years (1982-2018). Secondary data will be amassed from the Central Bank of Nigeria's Bulletin for the periods covered in the study.

\section{Model Specification}

Model specified in this study measured economic growth in terms of gross domestic product (GDP) and while public debt will be captured in terms of external debt (EXD) and domestic debt (DMD). Albeit, this study applied the Autoregressive Distributed Lag (ARDL) model as initiated by Pesaran Shin (1997) and Pesaran, Shin and Smith (2001) in the estimation conducted in the study. Both the short-run and long-run relationship of the variables of this study's model will be simultaneously estimated. However, the study also presents a regression model to track the causality relationship between GDP, EXD and DMD. The model is described below:

Functional Form

$G D P=f(E X D, D M D)$ $-3.1$

\section{Linear Form}

$G D P=\alpha_{0}+\alpha_{1} E X D+\alpha_{2} D M D+U----------------3.2$

\section{WHERE:}

GDP $=$ Gross Domestic Product

$\mathrm{EXD}=$ External Debt

DMD $=$ Domestic Debt

$\mathrm{U}=$ Stochastic Error Term

$\alpha_{0}, \alpha_{1}, \alpha_{2}, \alpha_{3}$ are parameter estimates corresponding to constants term, market capitalization all share index and value of transaction respectively.

Furthermore, the ARDL model for this paper can be demonstrated as:

$\mathrm{Y}_{\mathrm{t}}=\beta 1+\sum_{i=1}^{p} \beta_{i} y_{t-\mathrm{i}}+\varepsilon \mathrm{t}$

$\mathrm{Y}_{\mathrm{t}}$ is the level of economic growth at time $\mathrm{t}, \mathrm{y}_{\mathrm{t}-1}$ is the lagged value of economic growth at time $t i$, $\beta 1$ is the intercept, $\beta i$ are the trend parameters, $\varepsilon t$ is the normally distributed white noise with zero mean and constant variance; $\mathrm{p}=$ number of lags; $i=$ discrete value defined as $1,2,3, \ldots . . \mathrm{k}$.

The model displayed in equation (3.3) can be demonstrated in a single log form as follows:

$\mathrm{LGDPt}=\beta_{0}+\beta_{1} \mathrm{LEXDt}+\beta_{2} \mathrm{LDMDt}+\mu_{\mathrm{t}}$

ARDL framework for long run estimation model:

$\Delta \mathrm{LGDP}_{\mathrm{t}}=\alpha_{1}+\sum_{i=1}^{p} \psi_{1 \mathrm{i}} \mathrm{LGDP}_{\mathrm{t}-\mathrm{i}}+\sum_{i=1}^{p} \Theta_{1 \mathrm{i}} \mathrm{LEXD}_{\mathrm{t}-\mathrm{i}}+\sum_{i=1}^{p} \Theta_{2 \mathrm{i}} \mathrm{LDMD}_{\mathrm{t}-\mathrm{I}}+\varepsilon 1 \mathrm{t}$

Also, the short run coefficients of the proxies will be estimated with the ECM technique of the ARDL model. hence, the ECM model is shown below:

$\Delta \mathrm{LGDP}_{\mathrm{t}}=\alpha_{1}+\sum_{i=1}^{p} \psi_{1 \mathrm{i}} \Delta \mathrm{LGDP}_{\mathrm{t}-\mathrm{i}}+\sum_{i=1}^{p} \Theta_{1 \mathrm{i}} \Delta \mathrm{LEXD}_{\mathrm{t}-\mathrm{i}}+\sum_{i=1}^{p} \Theta_{2 \mathrm{i}} \Delta \mathrm{LDMD}_{\mathrm{t}-\mathrm{I}}+\varepsilon 1 \mathrm{t}$ 
Where

$\delta=$ represents the speed of adjustment parameters back to long-run equilibrium after short run shock.

$\alpha_{0}=$ represent the constant term

$\Delta=$ represent the first difference operator

$\pi=$ are the long-run coefficient

$\psi ; \theta=$ are the short-run dynamics

$\varepsilon t=$ is the white noise

\section{RESULTS AND DISCUSSION}

\section{Descriptive Analysis}

This section report descriptive statistics of all the variables used in the study including statistics for central tendencies, measure of dispersion, minimum and maximum values, degree of peakedness, asymmetric value, and the Jarque-bera statistics of all the series used in the study. Statistics reported in the section revealed measure of central location, how individual variable values are spread on each side of the centre via the root mean squared deviation (standard deviation). The peakedness of each variable is given by the kurtosis statistics, the symmetric nature given by skewness value while the normality status of each of the series is reflected by the JarqueBera statistics.

Table 4.1 Descriptive Statistics of Variables

\begin{tabular}{|l|c|c|c|}
\hline & GDP & EXD & DOD \\
\hline Mean & $1.85 \mathrm{E}+08$ & 26527364 & $9.48 \mathrm{E}+08$ \\
\hline Median & 95385819 & 29000000 & $3.23 \mathrm{E}+08$ \\
\hline Maximum & $5.68 \mathrm{E}+08$ & 46200000 & $4.91 \mathrm{E}+09$ \\
\hline Minimum & 27752204 & 9620000. & 10238400 \\
\hline Std. Dev. & $1.69 \mathrm{E}+08$ & 8802833. & $1.34 \mathrm{E}+09$ \\
\hline Skewness & 0.869947 & -0.146404 & 1.562766 \\
\hline Kurtosis & 2.261304 & 2.356631 & 4.287292 \\
\hline & & & \\
\hline Jarque-Bera & 5.508225 & 0.770310 & 17.61519 \\
\hline Probability & 0.063665 & 0.680345 & 0.000150 \\
\hline & & & \\
\hline Sum & $6.85 \mathrm{E}+09$ & $9.82 \mathrm{E}+08$ & $3.51 \mathrm{E}+10$ \\
\hline Sum Sq. Dev. & $1.02 \mathrm{E}+18$ & $2.79 \mathrm{E}+15$ & $6.49 \mathrm{E}+19$ \\
\hline & & & \\
\hline Observations & 37 & 37 & 37 \\
\hline
\end{tabular}

Source: Author's Computation, (2019)

Table 4.1 descriptive statistics of variables based on observation collected over the period spanning from 1982 to 2018. As reported in the table, the average value of gross domestic product, external 
debt and domestic debt stood at 1.85E+08, 26527364 and 9.48E+08 million US dollars respectively. Minimum and maximum value reported on table 4.1 stood at 95385819 and $5.68 \mathrm{E}+08$ for gross domestic product, 2900000 and 46200000 for external debt, 3.23E+08 and 4.91E+09 for domestic debt, all in million US dollars. Skewness statistics reported in table 4.1 revealed that all the variables used in the study are skewed to the right except external debt, with reported values of $0.869947,-0.146404$ and 1.562766 for gross domestic product, external debt and domestic debt respectively. Reported kurtosis statistics revealed that all the variables are platykurtic by the distribution peakedness. In specific terms reported kurtosis statistics stood at 2.261304, 2.356631 and 4.287292 for gross domestic product, external debt and domestic debt respectively. Jarquebera statistics reported in table 4.1 stood at 5.508225 $\quad(p=0.063665>0.05) \quad$ for gross domestic product, $0.770310(\mathrm{p}=0.680345>0.05)$ for exchange rate and $17.61519(\mathrm{p}=$ $0.000150<0.05)$ for domestic debt which demonstrates that all the variables are normality distributed.

\section{Correlation Analysis}

Table 4.2 Correlation Matrix

\begin{tabular}{|c|c|c|c|}
\hline & \multicolumn{1}{|c|}{ GDP } & EXD & DOD \\
\hline GDP & 1.000000 & & \\
\hline EXD & -0.243367 & 1.000000 & \\
\hline DOD & 0.855998 & 0.180394 & 1.000000 \\
\hline
\end{tabular}

Source: Author's Computation, (2019)

Table 4.2 reported correlation coefficient of pairs of variables used in the study. Result showed existence of negative correlation between external debt and gross domestic product, meanwhile a positive correlation was revealed between domestic debt and gross domestic product. Specifically, correlation statistics stood at -0.243367 and 0.855998 for EXD and GDP and DOD and GDP. The result reflects that domestic debt move predominantly in the same direction with gross domestic product, but external debt was observed to exert a negative connection on gross domestic product in the period covered in the study.

\section{Unit Root Analysis}

This section present summary of result of unit root test carried to ascertain the stationary property i.e. predictability properties of the variables. The test showed the order of integration of each of the variables, as presented in table 4.3 below. 
Print ISSN: 2052-6393(Print), Online ISSN: 2052-6407(Online)

Table 4.3 Summary of Unit Root Test Result

\begin{tabular}{|c|c|c|c|c|c|c|c|}
\hline \multicolumn{4}{|c|}{ At Level } & \multicolumn{4}{c|}{ At First Difference } \\
\hline Variables & $\begin{array}{c}\text { ADF } \\
\text { Statistics } \\
\text { \& Trend }\end{array}$ & $\begin{array}{c}\mathbf{1 \%} \\
\text { critical } \\
\text { value }\end{array}$ & $\begin{array}{c}\mathbf{5 \%} \\
\text { critical } \\
\text { value }\end{array}$ & $\begin{array}{c}\text { ADF } \\
\text { Statistics \& } \\
\text { Trend }\end{array}$ & $\begin{array}{c}\mathbf{1 \%} \\
\text { critical } \\
\text { value }\end{array}$ & $\begin{array}{c}\mathbf{5 \%} \\
\text { critical } \\
\text { value }\end{array}$ & $\begin{array}{c}\text { Order of } \\
\text { integration }\end{array}$ \\
\hline GDP & -3.286632 & -3.689194 & -2.971853 & -3.909255 & $-4.243644 *$ & -3.544284 & $\mathrm{I}(1)$ \\
\hline EXR & -1.875052 & -4.243644 & -3.544284 & -3.913997 & $-4.243644 *$ & -3.544284 & $\mathrm{I}(1)$ \\
\hline DOD & -3.783114 & -4.323979 & -3.580623 & -2.145825 & $-4.243644 *$ & -3.548490 & $\mathrm{I}(1)$ \\
\hline
\end{tabular}

Note: $*(*)$ connote significance at $1 \%$ and $5 \%$ significant levels respectively

Source: Author's Computation, (2019)

Unit root test result presented in table 4.3 reported Augmented Dickey Fuller (ADF) test statistics alongside critical values at $1 \%$ and $5 \%$ significant level respectively. Result showed that all the variables are not stationary at level, given the fact that the reported ADF statistics is less than the critical values both at $1 \%$ and $5 \%$ respectively. However all the variables become stationary after first difference, which implies that difference stationary, and integrated of order one I(1). Reported order of integration of the variables reflects how long the variables retained innovative shocks over the years. Observably result showed that all the variables used in the study only retain innovative shock passed on them for a short period of time, after which they let go. Following the confirmation of the variables being integrated of order one $\mathrm{I}(1)$, it is noteworthy that there is no equilibrium relationship among the variables in the short run with the existence of unit root. However there is likelihood of long run equilibrium relationship among the variable in the condition that they cointegrate. In the quest to justify this position, Johansen co-integration test was conducted and the result presented in the next section.

Co-integration Analysis

Table 4.4 Johansen Co-integration Test Result

Series: $G D P, E X D, D O D$

\begin{tabular}{|c|c|c|c|c|}
\hline Eigen Value & Trace Statistics & $\begin{array}{c}\text { 5 Percent } \\
\text { Critical Value }\end{array}$ & Probability & $\begin{array}{c}\text { Hypothesized No of } \\
\text { CE(s) }\end{array}$ \\
\hline 0.633442 & 56.33628 & 29.79707 & 0.0000 & None* \\
\hline 0.448702 & 21.21037 & 15.49471 & 0.0062 & At most $1^{*}$ \\
\hline 0.010475 & 0.368550 & 3.841466 & 0.5438 & At most 2* \\
\hline
\end{tabular}

* denotes rejection of the hypothesis at 1\% significance level

Trace test indicates 2 co-integrating eqn(s) at the 0.05 level

Source: Author's computation, (2019)

Result presented in table 4.4 above is the summary of co-integration test conducted in the study with respect to the model specified to examine the effect of public debt on economic growth of Nigeria. Trace statistics reported in table 4.4 revealed that there is strong evidence to reject the null hypothesis of no co-integration, in favour of two co-integration equation at $5 \%$ level of 
significance. This is to say that though there is no short run equilibrium relationship between public debt and economic growth, in the long run there is existence of equilibrium relationship. Hence the observed long run relationship is given by co-integration regression result presented in table 4.5 below.

Table 4.5 Co-integration Regression Result

Series: GDP, EXD, DOD

\begin{tabular}{|c|c|c|c|c|}
\hline Variables & Coefficient & Std. Error & t-statistics & Probability \\
\hline EXD & -8.493941 & 1.391421 & -6.104506 & 0.0000 \\
\hline DOD & 0.115607 & 0.008819 & 13.10856 & 0.0000 \\
\hline C & $2.98 \mathrm{E}+08$ & 38903498 & 7.661073 & 0.0000 \\
\hline
\end{tabular}

$R$-square $=0.894582$, Adjusted $R$-square $=0.888193$

Source: Author's Computation, (2019)

Estimation result presented in table 4.5 revealed that in the long run exchange rate exerts a negative and significant impact long run effect on gross domestic product, with reported coefficient estimate of -8.493941 ( $\mathrm{p}=0.0000<0.05)$. Also, it was evident in the above result that domestic debt exerts a positive and significant impact on gross domestic product with coefficient estimate of 0.115607 $(\mathrm{p}=0.0000>0.05)$. Reported R-square statistics stood at 0.894582 , which reflect that in the long run, external debt and domestic debt can jointly explain about $89 \%$ of the systematic variation in gross domestic product of Nigeria, other things held constant.

Vector Error Correction Model

\begin{tabular}{|l|l|l|l|l|}
\hline Variable & Coefficient & Std. Error & t-Statistics & Probability \\
\hline GDP & -.6018115 & .4070234 & .1969398 & 0.140 \\
\hline EXR & -.1108504 & .0514033 & -.0101017 & 0.031 \\
\hline DOD & .0861745 & 1.045089 & 2.134512 & 0.08 \\
\hline
\end{tabular}

Source: Author's Computation, (2019)

Table 5 shows that coefficient of error correction term of GDP has the speed of convergence towards equilibrium of 60 percent. In the short run GDP are adjusted by 60 percent of past years deviation from equilibrium. The large absolute value of the coefficient of ECM shows the speed of adjustment is very rapid towards equilibrium and low absolute values are indicating of slow speed of adjustment in the short run. It means that speed of adjustment of external debt towards equilibrium is slow in the short run. The coefficient of error correction term of GDP has negative sign and it is statistically insignificant at 5\% level. It implies that the system is convergent towards equilibrium but unstable due to the any disturbance in the system. The coefficient of error correction term of domestic debt is insignificantly positive at $5 \%$ level. It depicts stability of the system and convergence towards equilibrium path in case of any disturbance in the system. The coefficient of error correction term of domestic debt is positive but statistically insignificant at $5 \%$ level. It implies that the system convergence towards the equilibrium path and the system is stable, although insignificant. 


\subsection{Post Estimation Test}

\begin{tabular}{l|cc}
\hline & Chi-square stat & Probability \\
\hline Specification 1 & 5.09 & 0.2779 \\
Specification 2 & 4.77 & 0.3112 \\
\hline
\end{tabular}

Source: Author's Computation, (2018)

Table 4.7 revealed the result of post estimation test attained in the bid to track heterogeneity effect among sampled observations justified by the specification 1 and specification 2 with reported statistics of $5.09(\mathrm{p}=0.0 .2779>0.05)$ and $4.77(\mathrm{p}=0.3112>0.05)$ respectively. The JarqueBera post estimation test presented in table 7 revealed that there is no enough evidence to reject the null hypothesis; this implies that residuals of the specified model are normally distributed.

\section{DISCUSSION OF FINDINGS}

Result of estimation conducted in this study in the quest to quest to examine the effect of public debt on economic growth of Nigeria. Firstly, the result shows that external debt exerts a negative long run and short run effect on economic growth of Nigeria. This indicates that increases in external debt in Nigeria will trigger a reduced economic growth. External debt being an economic policy geared towards enhancing the productive capacity of the nation through the delivery of enduring assets and implementation of quality policies towards increasing the growth of the nation, it possesses the capacity to increasing the economic growth of the nation. But following the attained result, it is evident that external debts contracted in Nigeria over time are deadweight debt, this has over time exerted no critically negative impact on the growth level of the nation as evident in the result demonstrated in the study.

Again, the result shows that domestic debt was revealed that domestic debt exerts a positive long run and short run effect on economic growth of Nigeria. This implies that an increased internal, national or domestic debt usually contracted in the local currency of the debt country would control a favorable level of economic growth. This can be clearly justified from the total lack of exposure to currency risk posed by exchange rate misalignment. However, the result indicated in the study can be further defended from the aspect of monetary policy, government in the bid to command stability and sustainability in the state of the economic takes countercyclical actions with reasonable monetary policies e.g. issuing treasury bills; this action without doubt controls external shocks and makes functional the financial markets and institutions of the country and consequently positively affecting the economic growth of the country.

\section{CONCLUSIONS AND RECOMMENDATIONS}

Premise on the analytical results carried out in the study, it is evident that public debt has a varying relationship with economic growth. The study specifically established that external debt impacts negatively on economic growth of Nigeria both in the short run and long run while domestic debt possesses positive relationship with economic growth both in the long run and short run. Based on 
the findings of the study, we therefore conclude that public debt commands a relationship with economic growth depending on the form of debt contracted. Based on the findings ascertained in the study, the following policy recommendations become imperative.

i. Policy makers should integrate appropriate measures towards ensuring suitable management of domestic debts so as to enhance the productivity level of the country.

ii. Government should ensure that contracted national debts are directed towards encouraging investment in the country so as to increase capital formation in the country and consequently a sustainable economic growth.

iii. Government through necessary monitoring committees should ensure that national debts are directed toward the provision of basic amenities and services required for the development of communities and societies of the nation.

\section{REFERENCES}

Akhanolu, I.A., Babajide, A.A., Akinjare, V., Oladeji, T. and Osuma, G. (2018). The Effect of Public Debt on Economic Growth in Nigeria: An Empirical Investigation. International Business Management. 12(6), 436-441.

Akinwunmi, A.A. and Adekoya, R.B. (2018).Assessment of the Impact of External Borrowing on the Economic Growth of the Developing Countries-Nigerian Experience.Asian Business Research. 3(1), 29-40.

Alfred, G. (2014). Public Debt and the Dynamics of Economic Growth. Annals Of Economics And Finance 15-1, 185-204.

Amilcar, S. (2016).Impact of Public Debt on Economic Growth in Advanced Economies.International Journal of Managerial Studies and Research. 4(2), 70-76.

Blake, T. (2015).Investigating the Impact of Public Debt on Economic Growth in Jamaica. Fiscal and Economic Programme Monitoring Department Bank of Jamaica. 1-22.

Brini, Jemmali and Ferroukh (2016). Public Debt and Economic Growth in Tunisia: A Reexamination. Advances in Economics and Business 4(11), 584-590.

Brini, R, Jemmali, H. and Ferroukh, A. (2016). Public Debt and Economic Growth in Tunisia: A Re-examination. Advances in Economics and Business 4(11), 584-590.

Dada (2012). Effect of Public Debt on Economic Growth in Nigeria (1970-2009). First International Conference, Department of Management and Accounting, ObafemiAwolowo University Ile-Ife Nigeria. Conference Paper; 2-21.

Egbetunde, T. (2012). Public Debt and Economic Growth in Nigeria: Evidence from Granger Causality. American Journal of Economics. 2(6), 101-106.

Egbetunde, T. (2012). Public Debt and Economic Growth in Nigeria: Evidence from Granger Causality. American Journal of Economics. 2(6), 101-106.

Essien, S. E., Agboegbulem, N. T. L., Mba, M. K., and Onumonu, O. G. (2016).An Empirical Analysis of the Macroeconomic Impact of Public Debt in Nigeria.CBN Journal of Applied Statistics. 7(1), 125-136.

Favor, E.O., Ideniyi, O.S., Oge, E.O. and Charity, I.A. (2017). Public Debt and Economic Growth in Nigeria.Asian Research Journal of Arts \& Social Sciences. 4(3): 1-16. 
Favour, O.F., Ideniyi, O.S., Oge, E.O. and Charity, I.A. (2017).Public Debt and Economic Growth in Nigeria.Asian Research Journal of Arts \& Social Sciences. 4(3): 1-16.

Hadhek, Z. and Fatma, M. (2014).Debt and Economic Growth.Debt and Economic Growth. 4(2), 440-448

Ideniyi, Ogonna and Ifeyinwa (2016). Public Debt and Public Expenditure in Nigeria: A Causality Analysis.Research Journal of Finance and Accounting. 7(10), 27-38.

Idenyi, O.S., Igberi, C.O. and Anoke, C.I. (2016). Public Debt and Public Expenditure in Nigeria: A Causality Analysis. Research Journal of Finance and Accounting. 7(10), 27-38.

Idris, M. and Ahmad, T.S. (2017). The Productivity Of Public Debt Borrowing And Economic Growth In Sub-Saharan Region: The Nigerian Context. International Journal of Economics, Commerce and Management.5(6), 340-373.

Idris, M. and Ahmad, T.S. (2017). The Productivity Of Public Debt Borrowing And Economic Growth In Sub-Saharan Region: The Nigerian Context. International Journal of Economics, Commerce and Management. 5(6), 340-373.

Jernej, M., Aleksander, A. and Miroslav, V. (2014).The Impact of Growing Public Debt on Economic Growth in the European Union.Munich Personal RePEc Archive.1-14.

Khan, A.A., Rauf, A. Mirajul-haq, Anwar, N. (2016).The Impact of Public Debt on Economic Growth of Pakistan.International Journal of Academic Research in Economics and Management Sciences. 5(2), 46-56.

Matandare, M.A. and Tito, J. (2018).Public Debt and Economic Growth Nexus in Zimbabwe.Journal of Economics and Sustainable Development. 9(2), 84-89.

Matandare, M.A. and Tito, J. (2018).Public Debt and Economic Growth Nexus in Zimbabwe.Journal of Economics and Sustainable Development. 9(2), 84-89.

Mousa, T.A. and Shawawreh, A. (2017). The Impact of Public Debt on the Economic Growth of Jordan: An Empirical Study (2000- 2015). Accounting and Finance Research. 6(2), 114120 .

Mousa, T.A. and Shawawreh, A. (2017). The Impact of Public Debt on the Economic Growth of Jordan: An Empirical Study (2000- 2015). Accounting and Finance Research. 6(2), 114120.

Muhammad, D.A.B., Ruhaini, M., Nathan, S.B. and Arshad, (2017).Real effects of government debt on sustainable economic growth in Malaysia.Journal of International Studies.10(3), 161-172.

Muhammad, G.W. (2017). Public Debt And Economic Growth In The Southeast Asia Countries. JurnalllmuEkonomi. 6(1), 177-188.

Muhammad, G.W. (2017). Public Debt And Economic Growth In The Southeast Asia Countries. JurnalIlmuEkonomi. 6(1), 177-188.

Mwaniki, G.W. (2016). Effect of Public Debt on the Gross Domestic Product in Kenya.Journal of Economics and Finance.7(6), 59-72.

Naeem, A. (2017). Role Of Public Debt In Economic Growth Of Sri Lanka: An ARDL Approach. Pakistan Journal of Applied Economics. 27(2), 189-212.

Ndieupa, H.N. (2018). How Does Public Debt Affect Economic Growth? Further Evidence from CEMAC Zone.Asian Research Journal of Arts \& Social Sciences. 5(1), 1-8. 
Ndieupa, H.N. (2018). How Does Public Debt Affect Economic Growth? Further Evidence from CEMAC Zone.Asian Research Journal of Arts \& Social Sciences. 5(1), 1-8.

Nwankwo, A. (2010), "Nigeria to Raise N1trillion in new Foreign, Local Debts", Financial Standard. 10(494), 23-35.

Okoye, L. U., Modebe, N. J., Erin, O. A., \&Evbuomwan, G. O. (2013). Effect of external debt on economic growth: Evidence from Nigeria. Sustainable Economic Growth, Education Excellence, and Innovation Management through Vision 2020, 4046-4058.

Oyedele, O., David, J.O. and Omojola, S.O. (2016). Effects of Public Debt on Economic Growth in Nigeria (1970-2011). European Journal of Business and Management. 8(12), 52-61.

Panizza, U. and Presbitero, A.F. (2013). Public Debt and Economic Growth in Advanced Economies: A Survey. Swiss Society of Economics and Statistics. 149(2), 175-204.

Panizza, U., \&Presbitero, A. F. (2014). Public debt and economic growth: is there a causal effect?.Journal of Macroeconomics, 41, 21-41.

Pesaran, M. H., \& Shin, Y. (1999).An Autoregressive Distributed Lag modelling approach to cointegration analysis.Department of applied economics, University of Cambridge, England. A revised version of the paper presented at the symposium at the Centennial of Ragnar Frisch. The Norwegian Academy of Science and Letters, Oslo.

Pesaran, M. H., Shin, Y., \& Smith, R. J. (2001).Bounds testing approaches to the analysis of level relationships.Journal of Applied Econometrics. 16(1), 289-326.

Rafindadi, A.A. and Musa, A. (2018). An Empirical Analysis of the Impact of Public Debt Management Strategies on Nigeria's Debt Profile. International Journal of Economics and Financial Issues. 9(1), 125-137.

Rahman, N. H. A. (2012). How Federal Government's Debt Affect the Level of Economic Growth?.International Journal of Trade, Economics and Finance, 3(4), 323-326.

Rahman, N.H. (2012). How Federal Government's Debt Affect the Level of Economic Growth?.International Journal of Trade, Economics and Finance. 3(4), 323-326.

Reinhart, C. M., \&Rogoff, K. S. (2010).Growth in a Time of Debt, in «American Economic Review».In Papers and Proceedings. 100(2), 1-9.

Said, Y. and Yusuf, A.O. (2018). Public Debt and Economic Growth: Evidence from Tanzania. Journal of Economics, Management and Trade. 21(7), 1-12.

Saifuddin, M. (2016). Public Debt and Economic Growth: Evidence from Bangladesh. Global Journal of Management and Business Research Economics and Commerce. 16(5), 65-73.

Saifuddin, M. (2016). Public Debt and Economic Growth: Evidence from Bangladesh. Global Journal of Management and Business Research Economics and Commerce. 16(5), 65-73.

Serrao, A. (2016). Impact of Public Debt on Economic Growth in Advanced Economies.International Journal of Managerial Studies and Research.4(2), 70-76.

Siew-Peng, L. and Yan-Ling, N. (2015). Public Debt And Economic Growth In Malaysia. Asian Economic and Financial Review. 5(1), 119-126.

Siew-Peng, L. and Yan-Ling, N. (2015). Public Debt And Economic Growth In Malaysia. Asian Economic and Financial Review. 5(1), 119-126. 
International Journal of Business and Management Review

Vol.8, No.1, pp.18-38, January 2020

Published by ECRTD-UK

Print ISSN: 2052-6393(Print), Online ISSN: 2052-6407(Online)

Udoka, Chris O. and Anyingang, Roland A. (2010), "Relationship between External Debt Management Policies and Economic Growth in Nigeria "(1970-2006). International Journal of Financial Research Vol. 1(1), 1-19. 